\title{
The Emotion of Truth and the Racial Uncanny Aborigines and Sicilians in Australia
}

\section{FRANCESCO RICATTI}

UNIVERSITY OF THE SUNSHINE COAST

La razza maledetta, che popola tutta la Sardegna, la Sicilia e il mezzogiorno d'Italia ... dovrebbe essere ugualmente trattata col ferro e col fuoco-dannata alla morte come le razze inferiori dell'Africa, dell'Australia ...

The damn race that populates Sardinia, Sicily and Southern Italy ... should be treated equally with fire and sword-damned to death as the inferior races of Africa, of Australia...

Napoleone Colajanni, Per la razza maledetta ${ }^{1}$

The violence of a racialised society falls most enduringly on the details of life: where you can sit, or not; how you can live, or not; what you can learn, or not; who you can love, or not. Between the banal act of freedom and its historic denial rises the silence.

Homi Bhabha, The Location of Culture ${ }^{2}$ 
-THE EMOTION OF TRUTH

The central character of the novel Looking for Alibrandi is a 17-year-old named Josie. She is a third-generation Sicilian Australian girl who lives in Glebe, just a couple of kilometres from Redfern, the symbolic core of Aboriginal urban presence in Sydney. When she discovers that her friend Jacob lives in Redfern, she asks him, 'Redfern. Do you know that I've been in this country all my life and I've never spoken to an Aboriginal person?'3 Rita Wilson notes how this sentence 'highlights ... both the existence and relative inaccessibility of (multi)culture in Australia, where one lives among individuals, families and communities of many diverse cultures yet contact with these (multi)cultures can be difficult, rejected or ignored'. ${ }^{4}$ For me, the question posed by Josie shows the symbolic void imposed at a discursive level between migrant groups and Aborigines. After reading more than seven hundred letters written by Italian migrants in Australia in the 1950s and 1960s, I was struck by the limited number of references to Aboriginal people. 5 Even those rare references usually have nothing to do with actual encounters and social exchanges: a father complains that children at his daughter's school sit on the floor 'come gli aborigeni' (like Aborigines);' another man complains that 'le mano nere' ([sic] black hands) stole something from him. ${ }^{7}$ In this second case, it is not clear if 'le mano nere' is a reference to Aborigines or to Sicilians, 'la mano nera' being the infamous name often used in migratory contexts in reference to supposedly Sicilian-mafia gangs. ${ }^{8}$ This lack of clarity is mostly due to the limited literacy of the author, which makes the letter almost unintelligible. Yet this was also the first instance in which I noticed during my research a possible conflation between Aborigines and Sicilians in Italian migrant discourse.

I have suggested elsewhere that the silence about relationships between Aborigines and Italian migrants should not be read as evidence of a sort of ethnic or racial vacuum in which Italian migrants settled separate from Aboriginal and Torres Strait Islander people. Rather, it is a significant aspect of the complex and unresolved question about the racial and colonial role played by migrants in Australia. ${ }^{9}$ What is often ignored, if not actually silenced, is not only the richness and vitality of encounters between Italian migrants and Aborigines, including intimate stories of sexual relationships, romantic love and family life, but also the colonial role Italian migrants have played through their settlements and through their 
support of racist ideologies and policies. As argued by Joseph Pugliese, the colonial practices that Italians and other non-Anglo migrants carried with them to Australia have largely been ignored.10 The colonial ideologies and practices that non-Anglo migrants acquired and employed after arriving to Australia and in the process of settlement are also often unacknowledged. ${ }^{11}$ In her book Tapestry, Maria PallottaChiarolli tells of her mother Dora being taught to be fearful of black American soldiers stationed in Italy. Later, once in Australia, Dora was taught to hate and fear Indigenous people, often through openly racist and extremely offensive expressions. For instance, Aborigines were called 'boongs' and described to her as 'dirty diseasefilled thieves who were one step above animals'.12 Importantly, Pallotta-Chiarolli suggests an intimate connection between Italian and Australian racism, as well as the possibility for new generations to resist such legacy. Her book remains, however, a rare instance of literary memory and critical reflection on Italian migrants' colonial and racist attitudes towards Aborigines.

Through references to four anecdotes, this article approaches the complex and often neglected topic of the relationship between Sicilian migrants and Aborigines. What is particularly interesting in the encounters, social interactions and relationships between Sicilians and Aborigines, is that Sicilians have often themselves been victims of colonial exploitation and racial stereotyping in Italy and abroad. As I illustrate later in this article, Sicily's geographical proximity to Africa has sustained stereotypes of racial proximity between the Sicilians and the black others' of the African continent. Their alleged racial ambiguity has meant that Sicilian migrants, as well as other southern Italians (especially Calabresi), occupied for a long period a liminal and ambiguous position in the racial dichotomy, being at once (not enough) white and (almost) black; a position in which they could be(come) at the same time the colonisers and the colonised.

This article does not seek clear evidence that may structure a well-defined historical narrative about Sicilians' relationships with Aborigines. Instead, it identifies 'potentially dissident' stories within a 'decolonizing migrant historiography', moments of truth that may open up new dialogues, narratives and research. ${ }^{13}$ Here, truth is intended as an emotion. The emotion of truth is a concept that I employ to challenge simultaneously relativist and dogmatic ideas about the truth, as well as any attempt to reduce truth to only that which can be demonstrated, 
proved and inscribed into acceptable media. Here, I am not talking about a truth that produces emotions or is itself emotionally charged; nor I am interested in discussing if, when and how emotions may be (considered) true or objective or trustable. ${ }^{14}$ Furthermore, I am not referring to the feeling of truth, the impression that something is, might, should or must be true. Rather, I am suggesting that truth, as experienced by humans, shares many of the characteristics associated with emotions: it is expressed and performed, it has a cognitive value but cannot be reduced only to its cognitive function, and it is a matter of and a tool for contested discourses, performances and artworks. Thus, the emotion of truth is not to be addressed as an epistemological tool to obtain objective factuality, but rather as a gnoseological issue about the emotional relationship between past and present, and its impact on individual lives and social experiences. ${ }^{15}$

If one assumes truth, and therefore historical truth, to be an emotion, a corresponding methodology is required. This would need to expose the limitations of a teleological interpretation of history as a narrative of causes and effects based on factual evidences.16 I attempt to contribute to the development of such a methodology by retelling and reflecting on my personal uncanny encounters with Italian migrants in Australia, in an effort to conceptualise the fragile balance between the homely and the unhomely in migratory experiences as well as in academic research on migration. Through the use of historians' personal anecdotes, I intend to test the potential of an emotion of historical truth precisely where any claim of factual historical truth can be more easily challenged as not sustained by significant recorded evidences. In particular, I will suggest the value of these mainly unrecorded stories as moments of disruption to the alleged objectivity of researchand the related objectification of the scholar, as well as of the people whose stories she or he tells. For the same reason, I contest the devaluation of the oral transmission of knowledge, implicit in the rejection of evidences, such as anecdotes, that have not been locked into some form of (semi)permanent inscription (through writing, recording, photographs, and so on).

When reflecting on almost a decade of historical research into the lives of Italian migrants in Australia, I often find myself thinking about specific encounters with 
Italian migrants that have proved to be uncanny moments of disruption to the historical narratives I was trying to construct, as well as to the critical theories I intended to employ. Yet these encounters are often experienced outside the boundaries of 'valid' academic research, and therefore are rarely represented in a scholarly space. In the fields of oral history and anthropology, a typical response to this issue is summarised by Portelli's recommendation to never turn off the recorder while conducting interviews, even during breaks or the final greetings. As an experienced oral historian, Portelli knows all too well that often interviewees tell the most interesting stories and make the most striking comments outside the formal boundaries of the interview. He also suggests that turning off the recorder shows lack of respect, as it implies the interviewer is no longer interested in what the interviewee has to say. ${ }^{17}$

Another solution is the direct observation of and note-taking about certain social and cultural events, a method typical of ethnographers. Both these solutions, while they are within well-established ethical boundaries and recommended to all oral historians and anthropologists, do not explain why so much truth is revealed in moments consciously or unconsciously perceived by the interviewee-and often also by the interviewer-as being outside the formality of academic research. Furthermore, these solutions do not capture those moments of truth that originate from scholars' everyday conversations, meetings and experiences, reinstating instead the conviction that if historical evidence is to be academically valid, it must have been recorded. These moments of truth, I argue, are at the core of the scholarly work, especially when they have the potential to disrupt hegemonic discourses and narratives, as well as challenge the power of deafening silences and censored topics in defining reality. These moments of truth in fact come to constitute one of the most significant ways in which historians form their opinions about the matters they study. Yet the unscholarly nature of these unrecorded experiences means that often they are not addressed or even recognised as valuable scholarly material. Sometimes, historians overcome such limitations through the use of anecdotes in the opening or concluding parts of their papers and speeches. Yet these anecdotes are usually presented as ironic statements that remain largely at the margins of the proper scholarly discourse; they thus become the counterpoint to the more serious matters of history, playing the stylistic function of balancing the perceived necessary 
seriousness of a historical paper. ${ }^{18}$ My contention is that, in some instances, these moments of truth should instead be at the core of scholarly reflections. In other words, anecdotal evidence, which is usually confined to the function of an ironic embellishment, might play an essential and vital role in academic discourse, whenever the need arises for deep reflections on the nature of scholarly research, especially in those fields that aim to contest or complicate hegemonic perspectives.

In the following pages I will recount and discuss four anecdotes about encounters with three Italian migrants and the daughter of an Italian migrant man and an Aboriginal woman. These encounters have produced in me an uncanny reaction of anxiety as well as excitement, or what Kristeva refers to as 'frightened joyfulness'.19 This uncanny feeling derived from the characteristics of the stories, as well as from the characteristics of the encounters. ${ }^{20}$ First, many of the stories and memories were themselves about uncanny experiences and feelings. Migration itself is of course the realm of the uncanny, as migrants often struggle to familiarise with the unfamiliar, as well as to cope with feelings of mourning and nostalgia towards what used to be familiar. Second, memories are inherently uncanny. They recall events of the past while producing new images, stories and emotions. They prove the emotional nature of truth, and that history is constructed by going 'back to the future', rather than 'back to the past'. Furthermore, when a moment of truth emerges it is always uncanny, as it lets us experience the familiar from a new and unexpected perspective, or conversely relates something unfamiliar to our deepest knowledge and emotional understanding of life and society.

From my perspective, Italian migrants' usual narratives and rhetoric, with which I am well acquainted, might be suddenly challenged by a surprising story, comment or action that forces me to reassess my familiarity with a certain discourse, and my understanding of specific aspects of migration. On the other hand, from the migrants' perspective, my reflections and questions sometimes challenge them to reassess familiar interpretations of their lives through the lens of an outsider with a very different agenda. Finally, the fact that I am also a migrant means, on a personal level, I am familiar and intimate with some of their experiences, strategies, reflections and emotions. Yet, in many aspects, my experience of migration has been significantly different from that of the majority of 
Italians in Australia, and I can be at times unfamiliar with their personal experiences, and unsympathetic towards their ideological and political convictions.

The following four anecdotes, especially when considered together, have produced in me an emotion of truth. This emotion is personal, and therefore certainly influenced by the social and cultural constraints that define my privileged position in society as an educated, middle-class, white, able-bodied, heterosexual man. ${ }^{21}$ The emotion of truth, however, is neither simply relative, nor an attempt to impose a falsely objective truth from a hegemonic position. On the contrary, by recognising truth as an emotion, I attempt to create a space of dialogue, exchange and challenge that is not structured around an objective and teleological factuality, but at the same time does not regress into the postcolonial politeness of the falsely guilty white scholar who 'confesses' a position of privilege. Such admission of white guilt not only allows the hegemonic white scholar to feel good about him or herself while continuing to enjoy colonial and racial privilege but, in fact, by sustaining a relativist position, undermines the political and cultural potentiality of a powerful dialogue around the truth of racism and colonialism.

-THE FOUR ANECDOTES

1.

A couple of years ago I was talking to Mario Bosin,22 an elderly Italian who had migrated to Australia in the 1950s. I asked him about his initial impression of the Indigenous people of Australia. He replied that the first time he saw an Aborigine he was quite scared. He explained that he was from the Veneto region in Northern Italy, and therefore had not seen a Sicilian until he was twenty-one. As confirmed by the rest of the conversation, the northern Italian migrant strongly associated the racial appearance of Sicilians to that of Aborigines. Both experiences-his first encounter with a Sicilian at the age of twenty-one and his later encounters with Aborigines in Australia-elicited the same response of fear. It did not surprise me that the migrant expressed fear of 'the Other', but what was surprising and bizarre was the association he had made between Sicilians and Aborigines. 
2.

A few weeks later, I received a phone call from Carmelo Caruso, a Sicilian migrant who told me he had heard about my research on Italian migrants in Australia, and wanted to show me his book of memories. I ended up buying his book, originally published in 1998. ${ }^{23}$ In it, Caruso, who had migrated from Sicily in 1950, insists on his proud Sicilian identity and spends most of the book emphasising his contribution to the Italian community in Brisbane, to the larger community of Italians in Australia, and to Australian society more in general. Towards the end of the book, Caruso, a fervent Catholic, devotes two pages to discussion about a group of nuns who in the early 1970s educated and assisted Aboriginal children 'orfani $o$ abbandonati' (orphaned or abandoned). These two pages are an exemplary collection of racial stereotypes about Aboriginal children-who want to sleep on the floor, refused to use the toilet and did not wear shoes and clothes-and about Aboriginal adults, who did not 'appreciate' civilisation, and preferred to remain in a primitive state rather than working. Caruso argues that even when the nuns were successful in educating these children, they were often taken away by those parents who had initially abandoned them. ${ }^{24}$

3.

The third anecdote displaces the position of Italians in relation to Aborigines, as constructed in the two previous episodes. In a recent conversation, Teresa Rosa 25 told me that her father, who arrived in Australia at a young age with his parents after the war, is Sicilian, while her mother is Aboriginal of the Kalkadoon people, her husband is English. We had a nice conversation about personal stories that do not fit into any of the typical dichotomies that still profoundly influence so much social, cultural and political interactions in Australia. Most of her conversation seemed to concern her need and ability to reduce the anxiety of other people. Such anxiety derives at times from cultural differences; for instance we discussed the Italians' habit of staring at people, compared with the convention in Teresa's Kalkadoon community that prohibits younger people looking into the eyes of the elders. More often, however, it is the racial anxiety she needs to respond to, as if in twenty-firstcentury Australia a definite and unambiguous position within the racial dichotomy of black and white is still necessary. Interestingly, she noted how it was not only her 
own racial ambiguity that produced anxiety, but also the racial mixture of her own family of Sicilians, Aborigines and English. She remarked how in her family when her children were small it was often the fair skinned adult who carried the fair skinned children, and the darker skinned adult who carried the darker skinned children, so as to avoid the gaze, confusion and suspicion of people in public spaces such as supermarkets.

4.

Soon after I received my Australian citizenship, my Italian friend Marilena, a PhD student at the University of Sydney, argued she could never become an Australian citizen, as recognising the authority of the government in such manner would legitimise the colonial dispossession of Aboriginal land. That was an uncanny moment for me, as I was very familiar with such political views, which I had in fact shared for long time, and yet at the same time I felt as if she was somehow, unwillingly, trying to 'dispossess' me, to deny the legitimacy of my albeit pathetic attempt to build a stronger identity and a more solid 'home' in my country of migration, as well as, importantly, to get political rights that are denied to permanent residents in Australia. The anxiety I experienced, I soon became aware, was not to be resolved, but rather, as I will explain later, to be recognised as a central, constitutive aspect of the Uncanny Australia itself. More recently, Marilena posted some photos on Facebook of the Aboriginal Passport Ceremony in which she participated. In one of these photos, she smiles in front of a large banner with the Aboriginal flag and the words 'always was always will be Aboriginal land'. In an earlier post, she wrote: 'Yay-Yay-Yay I am going to get the Aboriginal Passport on this Saturday morning.' In more than one instance, while talking about racism, Marilena has told me about her own experience of being a 'terrona' from Sicily, transplanted in the north of Italy, in a town where many people were openly hostile towards southerners. I am not interested here in tracing a causal relation between her own experience of racism during childhood and adolescence as a Sicilian in the north of Italy, and her sensitivity towards the issues of racism, colonialism and dispossession of Aboriginal land. Rather, it might be more productive to consider the complex intertwining of colonial and racist histories that seems to trace an uncanny connection between Sicilians and Aborigines. 
-THE RACIAL UNCANNY

How can I make sense of these four differing and, at times, contrasting anecdotes involving Sicilians and Aborigines? How can I make sense of my own uncanny feelings, my disorientation when reflecting on the intricate pervasiveness of the racial and colonial dictate in contemporary Australian society, but also on the ability of people to move within such constraining nets, and strive, and grow, and love? How can I relate my work as an historian interested in migration and racism to the complex and emotional truth that seems to emerge when juxtaposing such contradictory stories? How do I respect all the persons and the stories told, and engage in meaningful dialogues with them, without a paternalistic and condescending attitude? These were all questions that developed from these encounters outside the proper context of research. Yet such encounters have had a profound emotional impact on me and are, of course, representative of many other experiences that, together with research and study, have shaped my understanding of racial relations in Australia, especially in regard to migration. These, I am not afraid to say, were moments in which a complex, ambiguous, contradictory, yet also powerful, emotion of truth emerged, producing in me anxiety as well as excitement; disorientation, as well as a chance for dialogue and re-orientation.

One could perhaps believe that the Italian migrant in the first anecdote was scared the first time he saw a Sicilian or an Aborigine because of, as he suggests, sheer unfamiliarity. I would rather argue that in both his first encounters, with a Sicilian and with an Aborigine, what was really frightening for him was actually his familiarity with a certain representation of the black, colonised Other. The unification of Italy resulted in a process of colonisation of the southern part of the country, or at least reinforced a colonial attitude towards it, according to which the alleged inferiority and infantilism of the southerners had to be addressed for the development of the nation. ${ }^{26}$ This process was also sustained by the argument that the south of Italy was culturally and racially closer to Africa than to Europe, an argument that has a long tradition and was still widespread in the first half of the twentieth century; in fact there are some recurrences even to the present day. The supporters of many Italian football clubs, for instance, often call the Neapolitans 'dirty Africans'. In the late nineteenth century and well into the twentieth century, this long tradition, supported by the 'scientific' theories of Italian anthropologists 
such as Lombroso and Niceforo, ${ }^{27}$ fostered in countries of Italian migration like the United States and Australia the idea that southern Italian migrants were not really white, that they were racially ambiguous, that they had a drop of black blood in their veins, that they were the 'Chinese of Europe'.28 In other words, Italian migrants, especially those from the south of Italy, occupied for a long time an ambiguous position between the racialised dichotomy of black and white. ${ }^{29}$ As a consequence of this racially ambiguous position, many Italian migrants, not only in the United States and well beyond the early twentieth century, experienced the uncanny feeling of being at once the racialised Others and the racists, having to identify emotionally as both the marginalised and the marginalising, and finding themselves in the paradoxical situation of defending their not-quite-white-enough status, for fear of being returned to the inferior category of blackness. ${ }^{30}$

I think it is even more obvious that Mario Bosin's fear of the Aborigine-the Indigenous black Other-had its origin in a certain familiarity with colonial representations of and discourse about the Indigenous as primitive, savage, cannibal. One could for instance recall the novels by Emilio Salgari (Il continente misterioso, 1894) and Luigi Santucci (In Australia con mio nonno, 1947), which both described Australia as a land inhabited by dangerous cannibal savages. ${ }^{31}$ These authors had actually never been in Australia and they both drew on a common repertoire of colonial imagery. Around three decades before Salgari, Ottavio Barsanti, a friar who was sent to Australia as a missionary, described the Aborigines he encountered in the following terms:

mettere assieme le ossa di un uomo di statura comune, vestirlo poscia di una ruvida pelle di maiale, dargli denti e occhi bianchi, naso corto e schiacciato, labbra grosse, e finalmente mettergli in capo un fascio di ispidi e sozzi capelli...

put together the bones of a man of average height, then dress him with a rough pig skin, give him white teeth and eyes, a short and flat nose, big lips, and finally put on his head a bunch of bristly, dirty hair... ${ }^{32}$

What is particularly interesting here is that the friar does not simply describe a colonial/racist stereotype of the Aborigine, but also, in inviting the reader to imagine the Aborigine, literally gives instruction on how to assemble one, through sentences such as 'put together the bones', 'dress him [that is, the bones] with a 
rough pig skin', 'give him white teeth and eyes', 'put on his head a bunch of bristly, dirty hair'. Later, he describes Aboriginal men as resembling skeletons and spectres. The whole description recalls the macabre action of an anthropologist from the colonial era literally putting together the remains of a dead Aborigine for a museum exhibition. The uncanny Other comes to occupy a liminal space between the living and the dead, not only in gothic literature but in the colonial representation of the Indigenous Other as spectre. ${ }^{33}$

The first anecdote illustrates more than the persistence of certain racial stereotypes. It also shows the way our reactions in front of the Other can at times be of fear, not because we are faced with something or somebody we don't know, but because we are in front of something or somebody whose Otherness is in fact strangely familiar. This strange familiarity is read by Sara Ahmed as an effect of recognition: she suggests that "when we look out "for strangers" we already know what we are looking for, that we are already familiar with what a stranger is supposed to be'. ${ }^{34}$ This first anecdote illustrates her point. Ahmed argues that such an interpretation is an alternative to Freud's interpretation of the uncanny feeling, in which the strange familiarity is due to the return of the repressed: something we had repressed comes back and is at the same time strange and familiar. ${ }^{35}$ Instead, I believe these two interpretations are perfectly compatible. The uncanny feeling towards the indigenous or the migrant Other as strangely familiar is of course the result of a colonial category of knowledge, a colonial recognition of how the Other is supposed to be, act, look and smell. But it is also an effect of historical memories of colonialism, violence and trauma that have been repressed, displaced and removed from historical memory and public discourse.

If Mario Bosin, the migrant from the north of Italy, could employ his racial sense of superiority towards both the Sicilian and the Aborigine, Carmelo Caruso, the Sicilian migrant in the second anecdote, could only construct his racial superiority towards the Aborigines. He is not scared by the black Other, but employs a rational discourse of colonialist superiority. At the same time, he refers only in a short paragraph in his book to the hostility of Australians towards Italians, but makes no reference to the hostility of northern Italian migrants towards southern Italian migrants. Furthermore, he does not note that most of the Australian hostility was towards dark(er) Italians, especially from the south, something that migrants from 
the north of Italy rarely fail to note when explaining why they have never experienced racism. His sudden, disquieting and uncanny inversion of the truth about the Stolen Generation, according to which Aborigines were stealing their own children away from the caring attention of the civilised nuns, as well as all his other colonialist and racist statements, must be read not only as a sudden reappearance of a certain Anglo-Australian and Italian colonial discourse, but also in the light of the first anecdote I presented. Caruso is Sicilian, and therefore he is distancing himself not only from the Indigenous uncivilised Other, but also from a certain perception of the Sicilian uncivilised Other, as historically perceived by the racial gaze of many Anglo-Australians, as well as many northern Italian migrants.

Within embodied otherness, it is the uncanny feeling towards the racialised Other that most effectively makes us understand the complex relationship Italian migrants have had with the (un)familiar. The concept of the uncanny helps us understand that the racism of many Italian migrants towards African Americans in the United States of America, Aboriginal people in Australia or more recent and allegedly darker migrants in these countries and elsewhere, is not the result of a frightening encounter with the Other, with the unfamiliar and with difference. It is rather the result of the return of what has been repressed from historical memory, namely the colonial character of Italian unification, Italians' own racist and colonial history, the colonial nature of many Italian migrants' settlement abroad, and the identification of southern Italians as the colonised, racialised others, in Italy and abroad. The appearance of the Other (the Indigenous, the African American, the more recent migrant), is supposed to produce a feeling of unfamiliarity, and so is often remembered and narrated by migrants. Yet such an encounter is usually not with the unfamiliar. Instead, it is with the strangely familiar, as it is an uncanny reminder of Italian colonial categories of knowledge, but also of Italian migrants own racialised otherness and marginalisation. If we fail to acknowledge the peculiar, ambiguous and complex nature of Italian migrants' racist attitudes and feelings, we therefore risk conflating such phenomena with other histories of racism and colonialism, or even more superficially with a generic, universalised and therefore naturalised form of xenophobia.

The racist and colonial attitudes of Mario Bosin and Carmelo Caruso, while revealing an often overlooked aspect of Italian migration to Australia-its 
complicity with colonialism - seem at the same time to reinforce the impression of a substantial distance between the Italian and the Aboriginal communities in Australia. The third anecdote, regarding Teresa Rosa, is therefore a fundamental reminder of the continuous opportunities for encounters and relationships between migrants and Aborigines. While reinstating the pervasiveness of racism in Australian society, the brief conversation between Teresa and me was also intermittently enriched by narrative fragments of life that made me speculate about stories of love, desire, intimacy. The focus here cannot be the story of her parents and her family, which would require an in-depth study of family documents and oral history interviews. Instead, I intend to focus on the impact the conversation had on my approach towards histories of intimate relationships between Italian migrants and Aborigines, as well as my understanding of the racial divide still informing Australian society.

Power relations in contemporary Australia often relate to the persistence of fantasies of whiteness, which are constructed around the racial dichotomy between white and black. Within such contexts, as recently argued by Shiells:

the experience of particular national groups and the Australian response to non-white immigrants have been studied in great depth. And yet the complicated racial status of continental Europeans has not been investigated with the rigour seen in the American context. Whiteness studies and immigration history have remained, to a great extent, stubbornly separate research fields. ${ }^{36}$

My conversation with Teresa brought together in my mind a series of encounters I had had, in which the racial status and colonial histories of Sicilians were uncannily juxtaposed against those of Aborigines. These fragments of truth began making sense of my previous rather confused intuition that the ambiguous and shifting racial status of Italians, especially southerners, may be more effectively studied and understood in spaces, real and imaginary, of emotional and affective contacts with Aborigines. ${ }^{37}$

Susanne Schech and Jane Haggis have contended that the centrality and power of whiteness relies on its racial invisibility; that is, on its claim to be non-racial. ${ }^{38}$ They further suggest that this denies the complexity of Australian society and the role of migrants at the core of contemporary Australian culture. Toula 
Nicolacopoulus and George Vassilacopoulos talk about the 'distinctively white Australian constructions of whiteness', suggesting the dominant white Australia needs to locate the foreigner-within as 'white-non-white' or as 'white-but-not-whiteenough'.39 As already discussed, this is particularly true for those southern Italian migrants who have migrated in large numbers to Australia in the last century, and whose perceived racial ambiguity has for a long time represented a reason for suspicion by Australian institutions. Perera argues that those who identify themselves as white impose their centrality on the Australian nation and society by marginalising both the internal and the external non-white Others. ${ }^{40}$ Hage suggests interpreting whiteness as a powerful fantasy of sovereignty. He further argues that a constituent part of this fantasy is the attempt to keep the dichotomies between White and Aboriginal and between Anglo and Ethnic clearly separated.41 My conversation with Teresa reinforced my opinion that the complex relationships between Sicilian migrants and Aborigines challenge such dichotomies and their separation. They do so not simply as a reminder of the complexity of Australian society, or as a challenge to the imaginary unity of the colonial nation, even in its multicultural version. They achieve this by locating Sicilian Aborigines at the core of Australian and Italian history, reminding us of the turbulent power of life in breaking the silences imposed by the racial and the ethnic dichotomies, and in inserting a different dissonant time into the narrative of the nation.

Catriona Elder, Cath Ellis and Angela Pratt posit that in contemporary Australia 'the "emotional" room allocated to exploring the effects of racism and colonialism in the nation-space is increasingly limited. Consequently, alternative and more complex imaginings of the nation, which were already peripheral, are marginalised further still'. ${ }^{2}$ A process of negotiation aimed at overcoming ethnic and racial discrimination will be possible only when Australian society as a whole is able to examine and analyse its complex structure, not only in the present and for the future, but also in its past. History, then, and, in this specific case, histories of encounters between Sicilians and Aborigines, plays an important role. The coffee room where I talked to Teresa literally became, for a few minutes, an 'emotional room', one of the many emotional and affective spaces in which new narratives of the nation might be(come) possible. 
The café where I discussed with Marilena her Sicilian roots, and my own selfconflicted decision to take on the Australian citizenship, was also an 'emotional room'. It was particularly the latter topic that produced in me an uncanny feeling, pushing me to reflect on the complex relationship between migration, multiculturalism and (post)colonialism. Within the specific context of (post)colonial Australia, the most effective application of the concept of the uncanny to date is to be found in Ken Gelder and Jane Jacobs' study of Aboriginal sacredness and identity, particularly in their focus on the uncanny feelings produced by the unresolved issue of colonial dispossession, whereby "what is "ours" may also be "theirs", and vice versa', so that 'one's place is always already another's place'.43 This book, while problematically overlooking the role of migrants in the uncanny Australia, is a vital reminder that we cannot fully address the racialised uncanny feelings of Italians (or other migrants) in Australia independently from the colonial history of this country and the role migrants have played in colonising and settling in an already dispossessed and colonised land. The unhomely feelings of migrants in Australia relates not only to the existential condition of migration, but also to a 'new home' that is already strongly contested. Migrants reproduce and mirror the colonisers while also being recognised by the colonisers, and paradoxically even by other migrants, as the inferior Others. From Aboriginal as well as non-Aboriginal Australian perspectives, migrants are at once familiar and unfamiliar, occupying simultaneously a hegemonic and non-hegemonic position. To rephrase Gelder and Jacobs' quote above, once we add migrants to the arena in which economic, cultural, social and political capital is contested, what is 'ours' may also be 'theirs' and 'theirs'.

Migrants therefore challenge the racial and political dichotomy of colonialism by introducing a further element of uncanniness into the picture of the Australian (post)colonial nation. At the same time the rhetorical celebration of multiculturalism, especially as expressed and constructed in reference to citizenship, also shows how Australian multiculturalism itself is 'an idiosyncratic manifestation of (rather than a departure from)' colonial history. ${ }^{44}$ While Marilena's criticism of migrants acquiring Australian citizenship struck at the core of Australia's contradictory and hypocritical multiculturalism, her posting on Facebook about her participation in the Aboriginal Passport Ceremony constituted another uncanny moment for me. Ostensibly, it seemed rooted in concepts, fantasies and 
hegemonic practices imposed by the (post)colonial ruling: the document of identity that 'allows' travel between nations, the re-enactment of some sort of bureaucratic formality around a desk, the uncanny representation of the familiar bureaucracy of exclusion becoming symbolic of Aboriginal struggle for rights over the Australian land. I am not at all arguing that this is the actual nature of the ceremony. ${ }^{45}$ Nor do I intend in any way to undermine the validity of Marilena's reasons for participating. I want to suggest, though, that in looking at her photographs of the ceremony, it was difficult for me to escape the uncanny perception of the structure of colonialism and exclusion paradoxically imposing itself in an act of reconciliation. ${ }^{46}$ This, I believe, is particularly significant when considering the actual counter-hegemonic political and cultural intentions of the ceremony, which, as Marilena argued in a response to a first reading of this article, should not be interpreted as part of the ideology of reconciliation. ${ }^{47}$ Importantly, the website of the ceremony states that 'This campaign, including the Ceremony, was inspired by the issuing of the Passports to Tamil asylum seekers detained indefinitely in Australia', and quotes at the same time the words of the Palestinian activist Rihab Charida, who argues: 'There are a growing number of us [migrants] that recognise that we are the beneficiaries of a great injustice inflicted on the Aboriginal and Torres Strait Islander Peoples.' This ceremony, in other words, intends to challenge at the core the contradictory, hypocritical and violent nature of multicultural Australia.

Marilena effectively challenges the limits of a linear understanding of colonial history, and thus also the hegemonic perspective of colonialism and multiculturalism, through her proud yet complex and ever-changing Sicilian-Global identity, and through her ability to connect through life itself such identity to different contexts of struggle for recognition, rights and happiness: those of southern Italians, of Aboriginal and Torres Strait Islander peoples in Australia, of Indigenous people in Brazil. Her Sicilian identity seems to connect Marilena's transnational life to the complex histories of Sicily and its people: histories of colonisation and domination, struggles for independence and social justice, and migration. Importantly, in responding to this article, she noted how her experiences of displacement in Australia, and her encounters with Aboriginal women, opened her eyes on her own identity. ${ }^{48}$ These are precisely the connections that open up the chance for third spaces of dialogue, negotiation and political engagement within a 
present social, cultural and political dimension in which history is not the straight road to a teleological destination, but rather a rich, complex, multidimensional map through which re-orientation becomes possible. ${ }^{49}$

-CONCLUDING REMARKS

In refusing a facile dichotomy between an imaginary mainstream hosting society (that is, 'the Australians') and an imaginary ethnic community of migrants ('the Italians', or 'the Italian Australians'), I interpret migrants' bewilderment and reorientation, exploitation and agency, loneliness and community, despair and hope, as elements of a complex and intense process of adjustment and negotiation between many different and intersecting individuals, groups and communities. From this perspective, the concept of the uncanny allows for an emotional interpretation that may challenge critically any reassuring narrative of (Italian) migration and settlement, any simplistic and self-absolving interpretation of (Italian) colonial histories and attitudes (including those relating to migration and settlement in countries like Australia), and any triumphant reading of (Italian) migrants' position, role and achievement within the societies to which they migrated. The aim of this article has therefore been twofold. On the one hand, I want to illustrate how the uncanny contributes to a more nuanced and fully articulated understanding of migration and its histories. On the other hand, I argue that, when considering the relationship between the uncanny and migration, references to specific historical contexts are required to avoid any generic, and always hegemonic, use of vague categories such as 'the Other', and so to give political weight to what otherwise threatens to remain an existential, at time almost transcendental, understanding of the impact of the uncanny in migrants' lives. What I am arguing for is not only the usefulness of the concept of the uncanny in migration studies, but the importance of historicising specific experiences of uncanny feeling. The uncanny may disrupt a linear and consistent narrative of cause and effect, which is often still employed in historical accounts, therefore disrupting 'our sense of a linear teleology in which the consecutive movement of history passes untroubled through generations'.50 At the same time the reference to specific historical contexts may complement as well as challenge existential and transcendental uses of this 
aesthetic concept, which often denies the geographical and historical specificity, and political potential, of uncanny experiences. ${ }^{51}$

In the interpretation of both Freud and Heidegger, and many other scholars after them, the uncanny is an anxious reaction to what is at once familiar and unfamiliar. This element of anxiety must be taken into consideration not only in our understanding of broad and widespread phenomena such as racism and xenophobia, but also in considering the emotional experiences of migrants, and the complex processes of negotiation between individuals and communities who intersect, meet and clash in the process of migration and settlement. Furthermore, the uncanny proves to be a very useful framework for understanding migrants' recollection of the past, and the relationship between memories of migration and settlement-individual and collective, private and public-and present ideologies and social practices.

In all the encounters described in this article, the present seems to be haunted by the past. ${ }^{52}$ Traditionally, historical narrative has been based on a cause-effect development from the past to the present-which in many instances has also come to justify the relevance of the historical discipline in the management of the future, from banal imperatives such as 'to know your future you must know your past', 'know the past, find the future', and all similar variants, to the actual use of historical studies in the development of public policies. This teleological understanding of history has been challenged by many scholars over the last two or three decades, but remains the prevailing approach within both academic and popular history. In recent years, my work in oral history has encouraged me to reflect more deeply on the impact historical memories have on the present, as well as the impact of prevailing current ideologies and discourse on the shaping of our historical memories. I have been struck by the continuous, fragmentary, ambiguous intertwining between past and present, where rather than a teleological factuality of past causes and present effects, I have perceived fragments of historical truth travelling back and forward into multidimensional emotional spaces. The past only seems to make provisional sense when it reaches an 'address' in the present, so that we struggle to travel 'back to the future', while being overwhelmed by our impotence in the face of a past that, as such, cannot be changed. By letting everyday discourse challenge the linearity of our prevailing historical narratives, we may 
come to realise the multidimensional complexity of our historical imagination, in turn addressing the relationship between past and present as a living, ever-changing emotion of truth: an emotional state with potential for cultural understanding, political activism, and social justice.

Francesco Ricatti is Cassamarca Senior Lecturer in Italian, School of Communication, Faculty of Art and Business, University of the Sunshine Coast.

I dedicate this article to my Sicilian ancestors.

\section{-ACKNOWLEDGEMENTS}

The initial idea for this article grew from conversations with Maurizio Marinelli and Teresa Rosa; I am very grateful to both of them. Grazie to Teresa and Marilena, for reading and commenting on this article with generosity, intelligence and sensitivity. I would also like to thank Naomi Stekelenburg, for her always intelligent and careful editing, the two peer reviewers for their valuable suggestions, and all the scholars with whom, in recent months, I have discussed the theme of the uncanny. I firstly approached such theme in relation to historical memory and xenophobia in an invited speech at the Moore Institute, National University of Ireland, Galway. I am particularly grateful to Paolo Bartoloni for his invitation, and also to his wife and children, Gem, Mia and Luca for their wonderful hospitality during my sunny week in Ireland. The trip was supported financially by the University of the Sunshine Coast, as part of my professional development program.

-NOTES

1 This would be the ultimate logic of the anthropologist Alfredo Niceforo's theories, according to Napoleone Colajanni's polemical interpretation of Niceforo's book La delinquenza in Sardegna (Remo Sandron, Palermo, 1897); see Napoleone Colajanni, Per la razza maledetta: osservazioni del dr. Napoleone Colajanni, Remo Sandron, Biblioteca della Rivista popolare vol. 1, Palermo, 1898, p. 32. It is worth noting that Niceforo was himself a Sicilian, and that Colajanni on the same page refers to the races of Africa and Australia as being 'systematically destroyed by the ferocious and wicked civilising men of Europe to steal their lands' ('che i feroci e scellerati civilizzatori sistematicamente distruggono per rubarne le terre'). 
2 Homi Bhabha, The Location of Culture, London and New York, Routledge, 1994, p. 15.

3 Melina Marchetta, Looking for Alibrandi, Penguin Books Australia, Melbourne, 1992, p. 63.

${ }^{4}$ Rita Wilson, 'Excuse Me is our Heritage Showing? Representations of Diasporic Experiences across the Generations', Flinders University Languages Group Online Review, vol. 3, no. 3, 2008, p. 107.

5 I am here referring to my research into letters sent by Italian migrants to Lena Gustin, the editor of a 'agony auntie' column in the Italian newspaper in Australia, La Fiamma, between 1956 and 1964. Lena and Dino Gustin, Papers, 1909-1992, Readers' correspondence, 1956-1964, ML MSS 5288 Add-on 1982/6-10(70), Mitchell Library, State Library of New South Wales. See Francesco Ricatti, Embodying Migrants: Italians in Postwar Australia, Peter Lang, Bern, 2011.

${ }^{6}$ L'Avventuriero di Peppino. Letter kept in Lena and Dino Gustin Papers, 1982/6.

7 Signora Lena, 2 September 1958. Letter kept in Lena and Dino Gustin Papers, 1982/6.

${ }^{8}$ The real or imaginary nature of 'la Mano Nera' is still debated. For a study of this phenomenon in the Australian context see Jonathan Richards, “"End the Canefields Terror”: True Italian Crime in North Queensland, 1932-1940', Spunti e Ricerche, vol. 24, 2009 [2011], pp. 42-54.

9 Ricatti, Embodying Migrants, pp. 42-3.

10 Joseph Pugliese, 'Crisis Heterotopias and Border Zones of the Dead', Continuum, vol. 23, no. 5, 2009, p. 670.

11 Curthoys has argued that the history of migration to Australia must be framed within a history of colonisation. See Ann Curthoys, 'Immigration and Colonisation: New Histories', UTS Review, vol. 7, no. 1, 2001, pp. 170-9.

12 Maria Pallotta-Chiarolli, Tapestry, Random House, Sydney, 1999, see in particular pp. 52 and 68-70.

${ }^{13}$ Joseph Pugliese, 'Migrant Heritage in an Indigenous Context: For a Decolonising Migrants

Historiography', Journal of International Studies, vol. 23, no. 1, p. 6.

${ }^{14}$ On this specific aspect, see Ronald De Sousa, Emotional Truth, Oxford University Press, New York, 2011.

${ }^{15}$ Although in English the word epistemology often refers to both epistemology and gnoseology, I think it is here important to maintain the difference between the two as employed in French and Italian philosophy, with gnoseology broadly referring to the philosophy of knowledge, and epistemology more specifically to the philosophy of scientific knowledge.

16 Carlo Ginzburg has suggested that historians should stop debating the nature of historical truth, and rather focus on 'a more subtle notion of historical proof ... which, for instance, takes into account all the special problems that confront us when we try to investigate matters that fall outside the traditional domain of historical science' (Carlo Ginzburg, inteviewed by Trygve Riiser Gundersen, 'On the Dark Side of History', Eurozine <http://www.eurozine.com/articles/2003-07-11-ginzburg-en.html>). While I agree with most of this statement, I also believe that, as the so-called 'history wars' in Australia have shown, a simple debate on proof and evidence does not solve the pressing gnoseological and political question of historical truth. In the same interview, Ginzburg recognises the risk, also emphasised by 
Žižek (Slavoj Žižek and Glyn Daly, Conversations with Žižek, Polity Press, Cambridge, 2004), of leaving truth in the hands of reactionaries. I argue that historians should avoid such risk, but at the same time should not ignore the fundamental challenges posed by postmodern and postcolonial history.

${ }^{17}$ Alessandro Portelli, 'A Dialogical Relationship. An Approach to Oral History', <http://www.swaraj.org/shikshantar/expressions_portelli.pdf>.

18 Here I am recalling a notation of Milan Kundera about the function of the comic counterpoint in Shakespeare's tragedies. See Milan Kundera, L'arte del romanzo, Adelphi, Milano, 1986, p. 150.

19 Julia Kristeva, Strangers to Ourselves, Columbia University Press, New York, 1991, p. 191.

20 The terms 'the uncanny' and 'uncanny' are here used in reference to the psychoanalytical and aesthetic theory of the uncanny, originally developed by Freud (Sigmund Freud, 'The "Uncanny"', in Sigmund Freud, Standard Edition, vol. 17 (1917-1919), pp. 219-52, originally published in German as Sigmund Freud, 'Das Unheimliche', Imago, 5 (5-6), pp. 297-34, pp. 219-52.), and which has subsequently been employed and re-elaborated by many scholars in literary and cultural studies (see the introduction to this special section; see also Anneleen Masschelein, The Unconcept: The Freudian Uncanny in Late-Twentieth-Century Theory, SUNY Press, Albany, 2011).

21 The possibility of engaging critically with one's own dominant or privileged position in society remains debated and highly controversial; see in particular Bob Pease, Undoing Privilege: Unearned Advantage in a Divided World, Zed Books, London and New York, 2010.

22 This is not his actual name. Some other details of this story have also been modified to ensure anonymity.

${ }^{23}$ Carmelo Caruso, Sotto un altro cielo: Vita e sentimento di un emigrante, Congedo Editore, Brisbane, 1998. For this essay the third edition of the book, published in 2008, was consulted.

24 Caruso, pp. 280-81.

25 This is not her actual name.

26 Gaia Giuliani, 'Il bianco negro. La "bianchezza” in Italia dall'Unità al Fascismo', Il Mulino, vol. 4, 2011, pp. 615-21; Michele Nani, Ai confini della nazione, Carocci, Roma, 2006.

27 Giuliani, p. 616.

28 Donna R. Gabaccia, "The "Yellow Peril" and the "Chinese of Europe": Global Perspectives on Race and Labor, 1815-1930', in Migration, Migration History, History: Old Paradigms and New Perspectives, eds Jan Lucassen and Leo Lucassen, Peter Lang, New York, 1997, pp. 177-96.

29 On the racial nature of Italian internal colonialism and its impact on Italian migration to Australia see Joseph Pugliese, 'Race as a Category Crisis: Whiteness and the Topical Assignation of Race', Social Semiotics, vol. 12, no. 2, 2002, pp. 149-68; Joseph Pugliese, 'Noi altri: Italy's Other Geopolitical Identities, Racialised Genealogies and Inter-Cultural Histories', in Literary and Social Diasporas: An Italian Australian Perspective, eds Gaetano Rando and Gerry Turcotte, Peter Lang, Bern, 2007, pp. 185202; Joseph Pugliese, 'White Historicide and the Return of the South of the South', Australian Humanities Review, no. 42, 2007. On the Australian perception of Italians as racially ambiguous also see 
Helen Andreoni, “'Olive or White?” The Colour of Italians in Australia', Journal of Australian Studies, vol. 27, no. 77, 2003, pp. 81-92; Vanda Moraes-Gorecki, “Black Italians" in the Sugar Fields of North Queensland: A Reflection on Labour Inclusion and Cultural Exclusion in Tropical Australia', The Australian Journal of Anthropology, vol. 5, no. 1-2, 1994, pp. 306-19; Catherine Dewhirst, 'Collaborating on Whiteness: Representing Italians in Early White Australia', Journal of Australian Studies, vol. 32, no. 1, 2008, pp. 33-49. For the impact of the racialisation of southern Italians in the broader context of Italian migration see Matteo Sanfilippo, Faccia da italiano, Salerno Editrice, Roma, 2011.

30 Sanfilippo, p. 83. For two significant examples of the racist struggle for whiteness of Italian migrants in United States and Brazil see Robert Orsi, 'The Religious Boundaries of an Inbetween People: Street Feste and the Problem of the Dark-Skinned Other in Italian Harlem, 1920-1990', American Quarterly, vol. 44, no. 3, 1992, pp. 313-47; Karl Mosma, 'Symbolic Conflicts, Deadly Consequences: Fights between Italians and Black in Western São Paulo, 1888-1914', Journal of Social History, vol. 39, no. 4, 2006, pp. 1124-52.

31 See Gaetano Rando, 'Recent Perceptions of Rural Australia in Italian and Italian Australian Narrative', Flinders University Languages Group Online Review, vol. 3, no. 3, 2008, p. 73.

32 Ottavio Barsanti, Selvaggi dell'Australia dinanzi alla scienza e al protestantesimo, Tipografia e Libreria Poliglotta, Tipografia e Libreria Pontificia, De Propaganda Fide, Pietro di G. Marinetti, Rome and Turin, 1868.

33 On the relation between the uncanny and spectral phantasies, see for instance Mladen Dollar, "I Shall Be with You on Your Wedding Night": Lacan and the Uncanny', October, vol. 58, 1991, pp. 5-23. On the use of the uncanny and spectrality in critical interpretations of Gothic literature, and later in other fields including postcolonial and migration studies, see the introduction to this section in this issue of Cultural Studies Review. Within the Australian (and Canadian) context, of particular relevance is the work of Gerry Turcotte on the relationship between the uncanny, the new Gothic literature and postcolonialism: see for instance Gerry Turcotte and Gaetano Rando, 'Diasporic Spectrality: Minorities and Cultural Assertions in Canada, Australia and Beyond', Australasian Canadian Studies, vol. 23, no. 2, 2005, pp. 1-11; Gerry Turcotte, Peripheral Fears: Transformation of the Gothic in Canadian and Australian Fiction, Peter Lang, Bruxelles, 2009; Cynthia Sugars and Gerry Turcotte (eds), Unsettled Remains: Canadian Literature and the Postcolonial Gothic, Wilfrid Laurier University Press, Waterloo Ontario, 2009.

34 Sara Ahmed, Strange Encounters: Embodied Others in Post-Coloniality, Routledge, London, 2000, p. 184.

35 Freud.

36 Georgia Shiells, 'Immigration History and Whiteness Studies: American and Australian Approaches Compared, History Compass, vol. 8, no. 8, 2010, p. 795. In the same page she further notes that 'there exists no book-length work on the shifting racial status of continental European immigrants in Australia'. 
37 To my knowledge there have been very few accounts of such relationships, and those there have been mostly fictional. See for instance the love story between a Sicilian man and an Aboriginal woman in Stanislao Nievo, 'Il tempo del sogno', in Stanislao Nievo, Il tempo del sogno, Mondadori, Milan, 1993, pp. 147-75, translated in English by Gaetano Rando as Stanislao Nievo, 'Dreamtime', in Riding Out: New Writing from Around the World, ed. M. Jurgensen, Outrider/Phoenix Publications, Brisbane, 1994, pp. 403-20. See also Emilio Gabbrielli, Polenta e goanna, Pontecorboli, Florence, 2000, translated in English by Barbara McGilvray as Emilio Gabbrielli, Polenta and Goanna, IpocPress, Milan, 2008; this is a novel that predates the documentary movie Hoover's Gold (2006), directed by Franco Di Chiera (see Gaetano Rando, 'Recent Perceptions of Rural Australia in Italian and Italian Australian Narrative', Flinders University Languages Group Online Review, vol. 3, no. 3, pp. 73-81).

38 Susanne Schech and Jane Haggis, 'Migrancy, Multiculturalism and Whiteness: Re-Charting Core Identities in Australia', Communal/Plural, vol. 9, no. 2, 2001, pp. 143-59.

39 Toula Nicolacopoulos and George Vassilacopoulos, 'Racism, Foreigner Communities and the OntoPathology of White Australian Subjectivity', in Aileen Moreton-Robinson (ed.), Whitening Race, Aboriginal Studies Press, Canberra, 2004, pp. 32-47.

40 Suvendrini Perera, 'Introduction: Fatal (Con)junctions', in Suvendrini Perera (ed.), Asian and Pacific Inscriptions: Identities, Ethnicities, Nationalities, School of English, La Trobe University, Melbourne, pp. 5-6.

${ }^{41}$ Ghassan Hage, White Nation: Fantasies of White Supremacy in a Multicultural Society, Pluto Press, Sydney, 1998.

42 Catriona Elder, Cath Ellis and Angela Pratt, 'Whiteness in Constructions of Australian Nationhood: Indigenes, Immigrants and Governmentality', in Whitening Race: Essays in Social and Cultural Criticism, ed. Aileen Moreton-Robinson, Aboriginal Studies Press, Canberra, 2004, p. 208.

${ }^{43}$ Ken Gelder and Jane M. Jacobs, Uncanny Australia: Sacredness and Identity in a Postcolonial Nation, Melbourne University Press, Melbourne, 1998, p. 138.

${ }^{44}$ Sneja Gunew, Haunted Nations: The Colonial Dimensions of Multiculturalism, Routledge, London and New York, 2004.

45 For an understanding of the actual characteristics and political aims of this ceremony, please visit the $<$ http://aboriginalpassportceremony.org>.

46 Pal Ahluwalia, 'Towards (Re)Conciliation: The Postcolonial Economy of Giving', Relocating

Postcolonialism, eds David Theo Goldberg and Ato Quayson Backwell, Oxford, 2002, pp. 184-204.

47 Personal communication by email with Marilena, 18 October 2012. I am very grateful to Marilena for the time she spent reading my article and expressing her concerns.

48 Personal communication by email with Marilena, 18 October 2012.

${ }^{49}$ On the concept of 'third space' see Homi Bhabha, 'The Third Space: Interview with Homi Bhabha', in Identity: Community, Culture, Difference, ed. Jonathan Rutherford, Lawrence \& Wishart, London, 1990, 
pp. 207-21; on orientation and re-orientation see Sara Ahmed, Queer Phenomenology: Orientations. Objects, Others, Duke University Press, Durham and London, 2006.

50 Peter Buse and Andrew Stott, 'Introduction: A Future for Haunting, Ghosts: Deconstruction,

Psychoanalysis, History, eds Peter Buse and Andrew Stott, London, Macmillan Press, 1999, p. 14.

51 See the introduction to this section of this issue of Cultural Studies Review for a more detailed argument on this point, especially in reference to the work of Derrida and Kristeva.

52 Jacques Derrida, Spectres of Marx: The State of the Debt, the Work of Mourning, and the New

International, Routledge, New York, 1994, originally published in French as Spectres de Marx, Editions Galileé, Paris, 1993. 